\title{
Linking the representation levels to a physical separation and purification method in chemistry: Understanding of distillation experiment
}

\author{
Nalan Akkuzu Güven ${ }^{1}$ and Melis Arzu Uyulgan ${ }^{2}$ \\ ${ }^{1}$ Dokuz Eylul University, Buca Faculty of Education, Turkey (ORCID: 0000-0003-3374-7293) \\ 2Dokuz Eylul University, Buca Faculty of Education, Turkey (ORCID: 0000-0002-2815-2642)
}

\begin{abstract}
The present investigation aims to analyze the knowledge levels and chemical representation levels of preservice primary school teachers (PPSTs) on the experiment of distillation. For this purpose, the crosssectional survey technique, one of the quantitative research designs was employed. The study was carried out at a Faculty of Education in the Aegean Region of Turkey with 79 freshman pre-service teachers enrolled in the Department of Primary Education. This group is of particular interest as they are the last class who had taken the General Chemistry course since this course was removed from the curriculum in 2018. A Distillation Experiment Worksheet (DEW), which consisted of 9 open-ended questions involving the macroscopic, sub-microscopic, and symbolic representations was used as data collection instrument in the study. The worksheets were analyzed with the document analysis method according to the categories created within the scope of the chemical representation levels, and these categories were established in line with direct statements of the PPSTs. Results indicated that PPSTs confused the heterogeneous and homogeneous mixtures, physical properties such as volatility and density, and they were unable to differentiate between boiling and evaporation. The most crucial result of the study was that the PPSTs had difficulties in establishing a relationship between macroscopic and sub-microscopic representations. For this reason, they could not demonstrate the interactions between solvent and solute molecules at the submicroscopic level during molecular dissolution and they could not predict how the intermolecular interaction changes during the condensation and the distance between the particles. Based on the results of this analysis, our study provides several recommendations for lecturers in the last part of this paper.
\end{abstract}

Keywords: Distillation; Macroscopic level; Sub-microscopic level; Symbolic level; Primary pre-service school teachers; Science education

Article History: Submitted 22 February 2021; Revised 23 June 2021; Published online 15 July 2021

\section{Introduction}

In primary school, i.e. in the $1^{\text {st }} 4^{\text {th }}$ grades basic science education that will be deepened and expanded further it is very important to form the basis of the students' knowledge in this content (Lamanauskas, 2009). Biology, physics, chemistry, technological, ecological problems constitute the content of basic science education. Providing students with basic information about these

Address of Corresponding Author

Nalan Akkuzu Güven, PhD, Dokuz Eylul University, Buca Faculty of Education, Mathematics and Science Education Department, 35380 , Izmir, Turkey.

nalan.akkuzu@gmail.com

How to cite: Akkuzu Güven, N. \& Uyulgan, M. A. (2021). Linking the representation levels to a physical separation and purification method in chemistry: Understanding of distillation experiment. Journal of Pedagogical Research, 5(3), 80-104. https:// doi.org/10.33902/JPR.2021370703 
problems in primary education will contribute to their competence to understand these phenomena and issues. So this will further remain a very meaningful sphere of the educational process in primary school (Lamanauskas, 2009). Science education in primary school is a basic step where students are acquired many skills such as creative thinking, effective communication, reasoning, and problem-solving (Harlen, 2004). The main objectives of science education include establishing a relationship between scientific and technological issues in daily life and helping students to apply what they learn to daily life (Ministry of National Education [MoNE], 2013). While students' cognitive skills related to science improve, their skills in practical life also develop, and then learning other subjects related to science education becomes easier for them. Thus, students experience 'how to learn'. The act of learning is the common goal of the teachers and the students. Science is one of the most difficult lessons in all education levels because the content of science does not consist entirely of concrete knowledge that can be obtained with the sense organs. To achieve accurate science learning, a teaching plan that includes abstract learning, as well as concrete learning, should be created. Chemical representations are used to create abstract learning such as the particulate structure of matter and to create correct images in the students' minds (Ainsworth, 2006; Corradi et al., 2012; Davidowitz \& Chittleborough, 2009). Overcoming the difficulties in science education and making the science lessons more enjoyable will be possible with qualified teachers who know how to teach and implement more effectively (Maltese et al., 2014). Furthermore, laboratory practices in science education provide students with the opportunity to establish a relationship between scientific theories and the material world (National Research Council [NRC], 2006). In this way, it will be ensured that students learn science and have scientific study experience (Alkan, 2016). On the other hand, a great number of studies have pointed out that many teachers at primary education have lack of science knowledge, or only have limited knowledge (Anderson et al., 2009; Hackling et al., 2007; Nilsson, 2008). In addition, some review studies have indicated that primary school teachers often have little, or no formal science training, and lack familiarity with the fundamentals of scientific inquiry (Capps et al., 2012; Roth, 2014).

Pre-service primary school teachers (PPSTs) who will educate in primary education have knowledge and skills on the courses "Basic Science in Elementary School, Teaching Science, and Laboratory Applications in Science" about science education (The Council of Higher Education [CoHE], 2018). The inability of PPSTs to get enough science content during their undergraduate education also has a negative effect on teaching activities at the primary education level (Çeken, 2010a). The difficulties faced by PPSTs in science content within the framework of the curriculum cause them to feel unwilling and inadequate in this field in their professional life (Uluçınar et al., 2008). This is because the pre-service teachers are unqualified in terms of theoretical knowledge in the science education courses they have taken at the university, and at the same time, they cannot fully experience the science education due to the lack of laboratory applications. In this context, it is extremely important to carry out studies in which theoretical knowledge is integrated into laboratory applications with PPSTs to eliminate these deficiencies. Based on this, with the present study, it is aimed to provide that the PPSTs have experience in the experiment of distillation, which is a separation method commonly used in the purification and separation of liquid-liquid and solid-liquid mixtures. The reason for selecting the experiment of distillation is that it includes basic phenomena and concepts such as homogeneous mixtures, boiling, evaporation, condensation, changes of state, and dissolution. In addition to this, it is stated in many studies that primary school teachers and the PPSTs have inadequate knowledge or misunderstandings on these issues (Papageorgiou \& Sakka, 2000; Papageorgiou et al., 2010, 2013; Phiri, 2008; Schulte, 2001; Uyanık, 2015). It is also thought that this study will help pre-service teachers better understand theoretical knowledge about distillation and reveal their deficiencies in this subject. For this reason, the study aims to determine the knowledge of PPSTs on distillation and to analyze their chemical representation levels on this subject. 


\subsection{The Content of Basic Science Education in Primary Schools}

The content of basic science education in primary schools such as chemistry, physics, and biology is constantly rearranged according to the needs of the age (Osborne \& Dillon, 2008). The content of the program taught is needed to be clear, attract attention and imagination, and also it should be encouraging to work intensively (Kennedy, 2013; Lamanauskas, 2003). It is necessary to teach science, which has a very wide content, to students in a properly organized program. In this sense, primary school teachers can have both sufficient and extensive knowledge about science (Appleton, 2007). In her longitudinal study, Lindahl (2003) claimed that the interest of the students in science mainly begins in the primary school period, and in this respect, the role of primary school teachers is of great importance.

According to Piaget, the age of 06-14, which is accepted as the primary education period, is the period in which the students get out of the concrete operational stage and reach the formal operational stage. In the concrete operational stage, while children develop the relationships, processes, and similarities of numbers and concepts, their mental abilities to think about problems also improve. However, they always think in terms of concrete objects, not abstract (Charles, 2000). Piaget stated that students in the concrete operational stage have basic skills such as reversing events, solving concrete problem situations, and classifying, while students in the formal operational stage have high-level skills such as hypothesizing, determining and defining variables, hypothetical thinking, and correlational thinking (Çepni, 2010). In this context, various chemical representations that facilitate the understanding of science should be used for the students who are in the concrete operational stage, and it should be aimed to present these representations in a way that concretizes the subject in their minds such as laboratory activities, models and other external representations.

Science education curriculum, which is expected to be implemented in primary schools, is a practical and concrete educational program that should be done with appropriate methods and techniques, taking into account the interests, needs, and requests of the students and classroom environment. Due to the complex structure of the science course, the students have difficulties in understanding and learn their subjects superfically. However, science education is a process based on the discovery of the real world. For this reason, it is clear that teaching by experimental method, which aims to provide an effective, permanent, and meaningful learning in science, is a studentcentered, active method, and aims to learn by doing and experiencing since primary education (Hodson, 2005; Hofstein et al., 2013). The main purpose expected in experimental applications is to ensure meaningful learning by experimenting and proving the theoretical knowledge that students have in the lessons (Nakhleh et al., 2002). Presenting science content related to abstract micro and macro universe to the attention of students in primary school science and technology lessons, and teachers' use of laboratory activities by nature illustrative or demonstrative in teaching this content enables easy and effective learning (Çeken, 2010b). Ferreira et al. (2015) stated that the design and implementation of experimental activities would result in successful learning outcomes. Furthermore, it is also recommended to use concrete concepts in science education, to make complex concepts understandable and to use modeling or external representations that make abstract concepts tangible and visible, i.e. concretizing, in order for students to have accurate knowledge (Gobert \& Buckley, 2000; Güneş et al., 2004; Harrison \& Treagust, 2000). At this point, we should recognize the importance of laboratory activities and chemical representations emphasized by many studies in science education in order to learn meaningfully and permanently.

\subsection{The Role of Chemical Representations in Science Education}

Epistemological explanations and representations in science are explained at three levels of chemical representations. Characterization of substances and changes in chemistry are described as macroscopic, microscopic, and symbolic levels (Kidanemariam et al., 2013). The chemistry educators are recommended to well explain these levels to their students and to pay attention to their explanations in order to avoid misunderstandings (Mahaffy, 2006). Chemistry education 
establishes descriptions and foundations specific to these levels; otherwise, students may face learning difficulties or develop conceptual misunderstandings.

The macroscopic level constitutes the observable dimension of substances, and this level can include the students' observations from their daily lives, such as changes in color, the creation of new products, and the disappearance of others. The language used by chemists in explaining this macroscopic level is usually at the level of symbolic representation, which includes pictorial, algebraic, physical, and computational forms such as chemical equations, symbols, chemistry formulas, graphs, reaction mechanisms, analogies, and model kits. Additionally, the third level is the sub-microscopic representation level which is based on the particle theory of matter. It is used to explain macroscopic phenomena in terms of the motion of particles (Treagust et al., 2003).

It is not sufficient to use macroscopic expressions alone while explaining the structure and properties of the substances. For example, graphite and diamond are both substances made up of carbon atoms. However, while explaining the properties of these substances, the microscopic and symbolic structure of the substance should also be considered (Kidanemariam et al., 2013). If we take water as a different example, boiling, melting, color, odor, etc. characteristics are frequently observed by students in their daily lives. However, the scientific accuracy of the knowledge needs to explain that these properties of water are due to its original microscopic properties. Learning the triple representations of substances and chemical phenomena correctly while explaining the structure of the substances can prevent students from experiencing any misunderstanding problems at the following stages of primary education. Therefore, the teachers should take into account that chemical identities (substances) and descriptions of chemical reactions or changes (process) should be explained by using pedagogy related to the nature of chemical explanations given to the respective representational levels (Erduran, 2005; Scerri \& McIntyre, 2008).

In the current primary education program, the learning outcomes of the units such as "Introduction to Matter" in the 3rd grade, and "Properties of Matter" in the 4th grade enable students to achieve basic chemistry subjects related to the matter (MoNE, 2013). It is thought that the studies to be conducted to determine the basic chemistry knowledge and chemical representation levels of PPSTs, who have an important role in teaching these knowledge to students for the first time, will be effective. Thus, teachers of the future, who will have sufficient and accurate knowledge about basic chemistry subjects and their concepts, will be able to teach students with in-depth knowledge of the subjects, not superficial, by using various chemical representations. The present study aims to analyze the knowledge levels and chemical representation levels of preservice primary school teachers (PPSTs) on the experiment of distillation. By considering this aim and the related theoretical framework, this study seeks to answer the following research questions:

- What are the PPSTs' levels of theoretical knowledge related to distillation?

- How do the PPSTs understand the experiment of distillation through macroscopic, submicroscopic, and symbolic levels of chemical representations?

\section{Method}

\subsection{Research Design}

In the present study, we used the cross-sectional survey technique, one of the quantitative research designs to find out answers to our research questions. According to Polit and Beck (2014), this research design is used in social science research to collect data on the behaviors, knowledge, attitudes, and respondent opinions and it can be used with many populations. In a cross-sectional study, a sample is chosen and data on each individual are collected at a certain point in time. Cross-sectional surveys can be considered a snapshot that gives a picture of what the researcher wants to study (Connelly, 2016; Hofer et al., 2002). Therefore, cross-sectional surveys provide highly appropriate temporal data on the characteristics of individuals. Based on the following research questions, the purpose of the cross-sectional study is to determine the macroscopic, submicroscopic, and symbolic representation levels of the PPSTs related to the experiment of 
distillation, which is one of the methods of separating mixtures. This study allows us to gather preliminary data to support further research and experimentation.

\subsection{Participants}

This study was conducted with 79 pre-service teachers in their first year of a primary school teacher education program who volunteered to take part in the study. The selection of the participants was carried out using the convenience sampling, which is one of the purposive sampling methods. Due to the limitations in terms of time and labour, participants are selected based on their being quickly and easily reached in this method (Yıldırım \& Şimşek, 2013). Although the total number of participants in two branches A and B was 101, some students initially included in the study $(n=22)$ could not participate in the study because of their absence. Therefore, the participation rate of the study was $78.2 \%(n=79) .65 .8 \%$ of the participants $(n=52)$ were female and $34.2 \%(n=27)$ were maleThe participants' ages range from 18 to 21 , with an average of 19.20. Since the participants' basic knowledge related to chemistry subjects came from the high school ninth grade level, their backgrounds were approximately the same. This study was implemented during the "General Chemistry" course, which was a required course that the students acquired their basic knowledge of chemistry in detail in the first year and spring semester of a primary school teacher education program. Since this course was removed from the curriculum in 2018, this research of that period has an important place in providing us with the fundamental knowledge of the pre-service teachers. Within the scope of the course, it was aimed to reinforce and improve the basic chemistry knowledge which was learned in primary and secondary schools and to eliminate their deficiencies, and to show their application by associating them with daily life. The fact that the participants were the individuals who took this course for the last time was also crucial in terms of the results that might arise.

\subsection{Data Collection Tools}

The Distillation Experiment Worksheet (DEW), which consisted of 9 open-ended questions, was prepared by the researchers in order to determine the levels of the subject matter knowledge of PPSTs and to analyze their chemical representation levels (macroscopic, sub-microscopic, and symbolic representation levels) on the experiment of distillation (see Appendix for questions). In the process of constructing DEW, the participants' backgrounds related to the chemistry subject knowledge were taken into consideration. While the DEW was created, the views of two experts' evaluations were obtained to ensure validity, and the worksheet was revised in line with their suggestions. The questions of DEW began with an example of daily life on removing nail polish stains, and it continued with questions about what kind of mixture the acetone-water mixture was, how this mixture was separated by the distillation technique, how the particle sizes and symbolic representations of the substances in the containers at different stages of the distillation experiment were. In this context, PPSTs were asked questions corresponding to all three levels of chemical representations. To assure their identity during the data collection, they were asked to use pseudonyms instead of their real names while filling out the DEW.

\subsection{Procedure}

Data were collected within the framework of a 2-week practice in the General Chemistry course taught in the 2018 spring semester. Prior to the data collection process, the participants were informed about the purpose and the scope of the research, and how the data would be used. At the first stage worksheets regarding the experiment of the distillation of acetone-water mixture were administered by the researchers to the PPSTs. In the meantime, the distillation experiment was presented to the PPSTs in two steps respectively, both as a demonstration and as a sample animation video. In this regard, a demonstration experiment on simple distillation was carried out by the researchers in the classroom environment. In the demonstration experiment, a simple distillation system was set up for how the acetone-water mixture was separated and the stages of the experiment were illustrated to the students. Following this demonstration, an animation 
experiment video on the simple distillation of removing nail polish stains was shown. Meanwhile, the PPSTs wrote down their opinions on the questions of DEW involving the macroscopic, submicroscopic, and symbolic representations. The process steps summarizing the implementation followed in this study are presented in Figure 1.

Figure 1

The implementation process of the study

$\Rightarrow \begin{gathered}\begin{array}{c}\text { Administering } \\ \text { DEW regarding } \\ \text { the simple } \\ \text { distillation }\end{array} \\ \begin{array}{c}\text { Informing the about the } \\ \text { purpose and the } \\ \text { scope of the } \\ \text { research }\end{array}\end{gathered} \Rightarrow \begin{gathered}\begin{array}{c}\text { Implementing } \\ \text { the } \\ \text { demonstration } \\ \text { experiment }\end{array}\end{gathered} \Rightarrow \begin{gathered}\text { Having the } \\ \text { PPSTs fill out } \\ \text { questions on } \\ \text { DEW }\end{gathered}$

Distillation of the acetone-water mixture was selected in both displays. The stages of the demonstration experiment and animation video are presented in Table 1.

Table 1

The stages of demonstration experiment and animation video

\begin{tabular}{|c|c|c|}
\hline Stages & Demonstration Experiment & Animation Video Experiment \\
\hline 1 & $\begin{array}{l}\text { At the first stage, the acetone-water mixture } \\
\text { is transferred to the distillation flask. }\end{array}$ & $\begin{array}{l}\text { Nail polish is poured on a child's glasses in } \\
\text { the video. }\end{array}$ \\
\hline 2 & $\begin{array}{l}\text { A boiling chip (stone) is added into this } \\
\text { mixture. }\end{array}$ & $\begin{array}{l}\text { He researches how to remove nail polish and } \\
\text { finds out that it can be removed by acetone. }\end{array}$ \\
\hline 3 & $\begin{array}{l}\text { The mercury chamber of the thermometer is } \\
\text { placed at the mouth of the balloon in line } \\
\text { with the steam exit hole of the distillation } \\
\text { balloon. }\end{array}$ & $\begin{array}{l}\text { Starting from this point of view, he learns } \\
\text { that acetone can be obtained by simple } \\
\text { distillation. }\end{array}$ \\
\hline 4 & $\begin{array}{l}\text { A simple distillation system is set up and } \\
\text { cold water passes from the condenser. }\end{array}$ & $\begin{array}{l}\text { He performs an activity to understand } \\
\text { simple distillation. }\end{array}$ \\
\hline 5 & $\begin{array}{l}\text { A beaker is kept at the outlet of the } \\
\text { condenser. }\end{array}$ & $\begin{array}{l}\text { He takes a mixture of acetone and water into } \\
\text { a distillation flask and puts a thermometer in } \\
\text { it. He connects the flask to a water condenser. }\end{array}$ \\
\hline 6 & The distillation flask begins to heat. & $\begin{array}{l}\text { The condenser has cold water running } \\
\text { through its jacket to keep the temperature } \\
\text { cool. He keeps a beaker at the outlet of the } \\
\text { condenser. }\end{array}$ \\
\hline 7 & $\begin{array}{l}\text { When the temperature starts to increase in } \\
\text { the distillation process, the liquid with a low } \\
\text { boiling point (acetone) evaporates and } \\
\text { becomes concentrated in the cooler, and } \\
\text { begins to collect. }\end{array}$ & $\begin{array}{l}\text { He heats the mixture keeping an eye on the } \\
\text { thermometer. When the temperature hits } 56 \\
\text { degrees celsius, acetone vaporizes. }\end{array}$ \\
\hline 8 & $\begin{array}{l}\text { The process is continued until approximately } \\
80 \% \text { of the mixture is distilled. }\end{array}$ & $\begin{array}{l}\text { These vapors condense in the water } \\
\text { condenser. The condensed acetone gets } \\
\text { collected in the beaker. In this way, acetone } \\
\text { and water get separated by simple } \\
\text { distillation. }\end{array}$ \\
\hline 9 & - & $\begin{array}{l}\text { He removes nail polish on his glasses by the } \\
\text { acetone obtained. }\end{array}$ \\
\hline
\end{tabular}

\subsection{Data Analysis}

Since DEW was used as a document in this study, they were analyzed with the document analysis method based on the theoretical framework of the study. Documents provide the researcher with information about things that cannot otherwise be observed and they enable to uncover meaning, and discover insights relevant to the research problem (Patton, 2002). Documents can be identified 
according to the analytical categories and the content of them should be systematic (Wach \& Ward, 2013). In this context, the categories were created according to the chemical representation levels and they were established in line with direct statements of the PPSTs. The written responses and drawings were coded depending on four categories that were correct, partially correct, incorrect, and no answer (N/A) in line with certain criteria (Coştu et al., 2005). "Correct" responses correspond to the PPSTs' answers that matching with the scientific knowledge, "Partially correct" responses include PPSTs' answers that overlap with scientific knowledge but contain missing information about the question. "Incorrect" responses include answers that do not correspond to scientific knowledge, and "N/A" means that are not answered or whose responses are meaningless. From the written statements of the PPSTs, not only was it possible to find how they formed associations for the chemical representations, it was possible to discover where they had difficulties related to chemical representations on distillation subject. The analyses with regard to the chemical representations were done by frequencies within the PPSTs' responses. The results of the analyses in line with chemical representations were presented descriptively in the form of frequency (f) and percentage (\%) values. In this regard, the data were analyzed by two researchers independently and inter-rater reliability scores were calculated as 0.98 and this value corresponds to high reliability (Miles \& Huberman, 1994).

\section{Results}

In order for the PPSTs to easily establish the relationship between distillation and daily life, the students were asked to make the necessary explanations on the first question of "How can you remove the nail polish on the eyeglass?". In Figure 2, it can be seen that although most of the students responded with correct answer, a substantial portion of them gave incorrect answers.

Figure 2

PPSTs' responses to the 1st question presented with their frequency and percentage distribution by categories

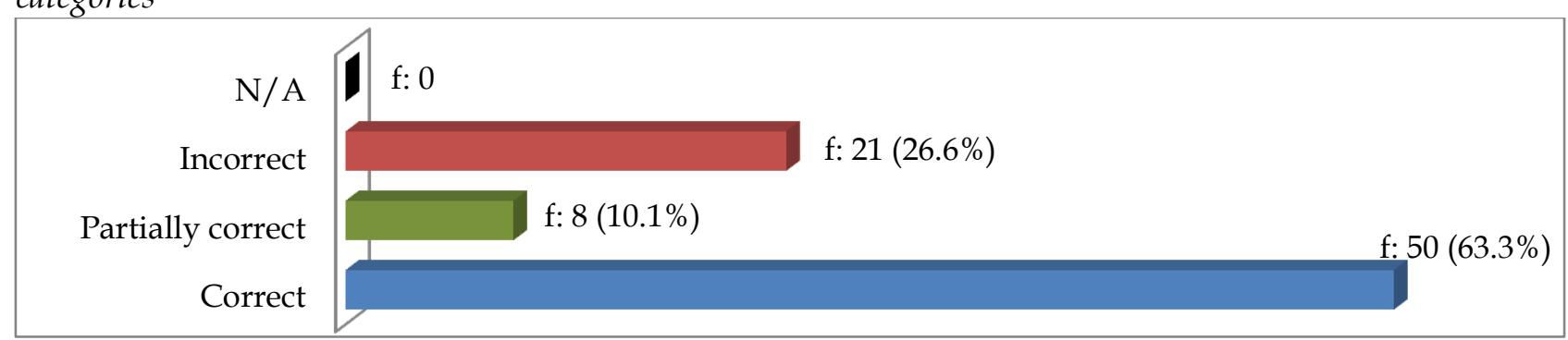

When examining the statements of the PPSTs regarding this question, which was at the macroscopic level, we determined that they made explanations corresponding to this level (see Table 2). Most of the pre-service teachers stated as the correct answer that the nail polish was removed with acetone because it was not dissolved in water. However, a significant number of preservice teachers expressed that acetone had cleaning properties because it contained alcohol, and nail polish stain could be removed with an acidic solution or cologne. Although the pre-service teachers who answered the question partially correctly stated that the thinner could be used for nail polish remover, they did not mention that removing could be possible with synthetic thinner or thinner with auxiliary substances.

A demonstration experiment was conducted by giving a sample of the acetone-water mixture in the classroom environment to help pre-service teachers understand distillation. In this context, we asked pre-service teachers what kind of a mixture of acetone-water can be separated by the distillation technique (2nd question), and asked them to explain the reason for this. Regarding the 2 nd question, it was aimed to determine which chemical representation levels the pre-service teachers used to explain the acetone-water mixture. $31.6 \%$ had incorrect answers while $51.9 \%$ of the pre-service teachers had correct answers (see Figure 3). 
Table 2

The results of the analyses of the PPSTs' responses to the first question

\begin{tabular}{|c|c|c|c|}
\hline $\begin{array}{l}\text { Representation } \\
\text { Levels }\end{array}$ & Statements & $\begin{array}{l}\text { Accuracy } \\
\text { Levels }\end{array}$ & $f$ \\
\hline \multirow[t]{5}{*}{ Macroscopic } & $\begin{array}{l}\text { It is removed with acetone. Because nail polish is not } \\
\text { soluble in water. }\end{array}$ & Correct & 50 \\
\hline & $\begin{array}{l}\text { It is removed with acetone. Because there is alcohol in } \\
\text { acetone that removes the stain. }\end{array}$ & Incorrect & 14 \\
\hline & $\begin{array}{l}\text { Since acetone will create scratches on the eyeglass it } \\
\text { can be removed with thinner. }\end{array}$ & $\begin{array}{l}\text { Partially } \\
\text { correct }\end{array}$ & 8 \\
\hline & $\begin{array}{l}\text { With an acidic solution. Because acids are an excellent } \\
\text { solvent for very strong stains. }\end{array}$ & Incorrect & 4 \\
\hline & It is removed with cologne. & Incorrect & 3 \\
\hline
\end{tabular}

Figure 3

PPSTs' responses to the 2 nd question presented with their frequency and percentage distribution by categories

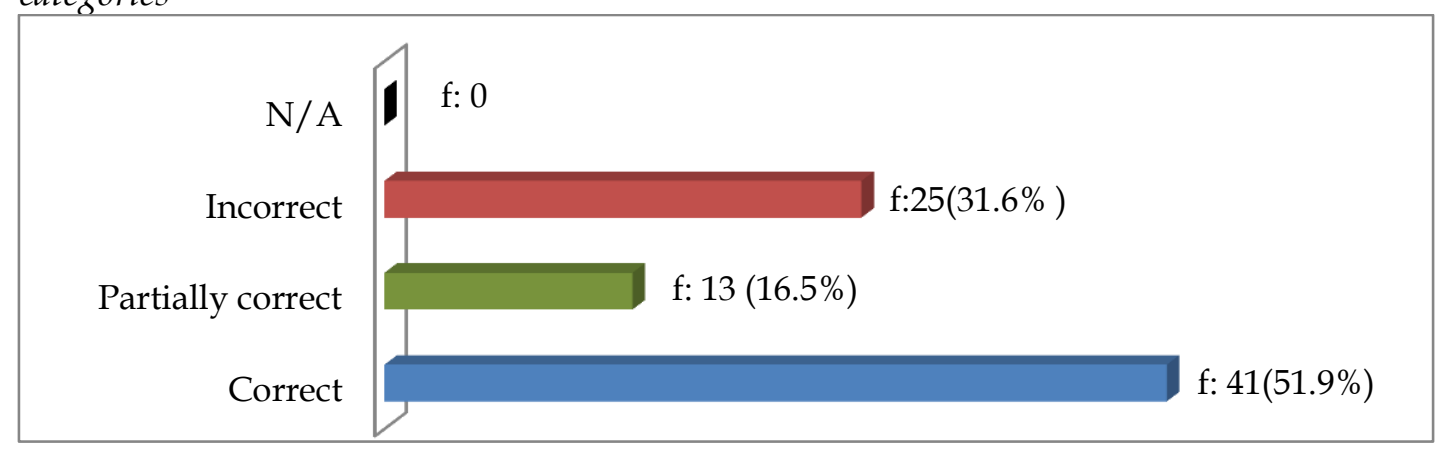

As the analysis results of the pre-service teachers according to the chemical representation levels of the 2nd question are examined, it is seen that their statements were at the macroscopic and sub-microscopic levels (see Table 3). Although the pre-service teachers observed the experiment with the demonstration technique, a significant number of them made incorrect explanations. For instance, 25 pre-service teachers stated that this mixture was heterogeneous by putting forward various inaccurate reasons. As the explanations they suggested were considered, they thought about this mixture in two phases and could not think about the dissolution phenomenon. Parallel to this finding, despite the fact that some pre-service teachers stated that acetone-water mixture was a homogeneous mixture in their explanations, they attributed this due to the presence of alcohol. Also, some pre-service teachers expressed that the mixture was homogeneous or heterogeneous because their densities were equal or different. Some of the PPSTs who made explanations at the sub-microscopic level were able to explain that the acetone-water mixture was a homogeneous because the dissolved particles were spread evenly throughout the mixture. On the other hand, pre-service teachers who made explanations at the particulate level had incorrect answers by stating that it was a heterogeneous mixture. 
Table 3

The results of the analyses of the PPSTs' responses to the 2 nd question

\begin{tabular}{|c|c|c|c|}
\hline $\begin{array}{l}\text { Representation } \\
\text { Levels }\end{array}$ & Statements & Accuracy Levels & $f$ \\
\hline \multirow[t]{6}{*}{ Macroscopic } & $\begin{array}{l}\text { It is homogeneous. Because when viewed from all sides, } \\
\text { it looks like a single phase. }\end{array}$ & Correct & 28 \\
\hline & $\begin{array}{l}\text { It is a heterogeneous mixture and is a type of emulsion. } \\
\text { Since their densities are different, they do not dissolve in } \\
\text { each other. }\end{array}$ & Incorrect & 12 \\
\hline & $\begin{array}{l}\text { It is a homogeneous mixture. Because acetone contains } \\
\text { alcohol. }\end{array}$ & $\begin{array}{l}\text { Partially } \\
\text { correct }\end{array}$ & 10 \\
\hline & $\begin{array}{l}\text { It is a heterogeneous mixture and is a type of emulsion. } \\
\text { Because it is a liquid-liquid mixture. }\end{array}$ & Incorrect & 4 \\
\hline & $\begin{array}{l}\text { It is homogeneous. Because they can dissolve into each } \\
\text { other. }\end{array}$ & Correct & 3 \\
\hline & $\begin{array}{l}\text { It is a homogeneous mixture. Because their density is } \\
\text { equal. }\end{array}$ & $\begin{array}{l}\text { Partially } \\
\text { correct }\end{array}$ & 3 \\
\hline \multirow[t]{2}{*}{$\begin{array}{l}\text { Sub- } \\
\text { microscopic }\end{array}$} & $\begin{array}{l}\text { It is a homogeneous mixture. Because the dissolved } \\
\text { particles are spread evenly throughout the mixture. }\end{array}$ & Correct & 10 \\
\hline & $\begin{array}{l}\text { It is a heterogeneous mixture. Because the acetone } \\
\text { particles are not evenly distributed through the water. }\end{array}$ & Incorrect & 9 \\
\hline
\end{tabular}

The PPSTs who observed the demonstration experiment and animation video were asked question 3 "How do the particles of acetone-water mixture move before heating in the distillation flask? Explain and draw the appearance of the particles in the distillation flask." The main purpose of this question was to determine how pre-service teachers imagine the movements of the particles in a homogeneous mixture by putting forward their reasons. The results of the analysis revealed that most of the pre-service teachers $(58.2 \%)$ had partially correct drawings, $36.7 \%$ of them had incorrect drawings while a few of them $(5.1 \%)$ were able to draw the movements of the particles correctly (see Table 4). Drawings coded as partially correct, PPSTs were generally only able to illustrate the distribution of acetone-water molecules homogeneously; however, they could not establish the intermolecular interaction. On the other hand, some of the PPSTs with incorrect drawings had great difficulty in drawing at particulate level, and some of them thought that the mixture as a heterogeneous mixture and usually drew the acetone molecules at the top of the mixture (see Figure 4). This finding might be due to the fact that they consider that acetone is the first substance to evaporate and/or the difference in density.

Figure 4

Examples of the drawings by the PPSTs in response to question 3

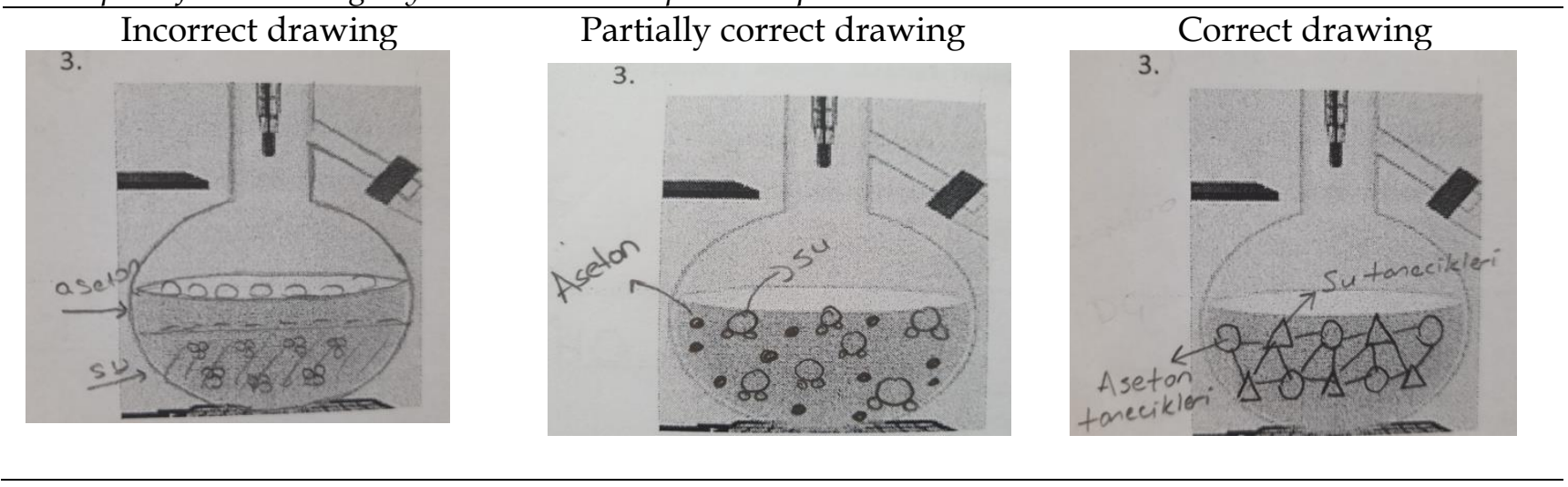


As the reasons for the pre-service teachers' drawings were examined in Table 4, very few preservice teachers who had the correct drawings were able to express the interaction of water and acetone molecules based on the phenomenon of the dissolution. Some of the pre-service teachers with partially correct drawings were able to state that there was a dissolution phenomenon and that the particles were evenly spread throughout the mixture because it was homogeneous; however, they could not show the distribution of particles in their drawings as in molecular dissolution and the formation of acetone-acetone, acetone-water or water-water intermolecular interactions. A remarkable finding was that some pre-service teachers stated that particles were adjacent in such $a$ homogeneous mixture. In this case, PPSTs assumed the formation as a compound because they could not consider intermolecular interactions. Another explanation that was encountered related to whether the particles in a homogeneous mixture were very close to each other or apart. The PPSTs expressing the homogeneous mixture in this way had drawn the particles separately or adjacent to it. Some pre-service teachers demonstrated acetone molecules on the water molecules by giving incorrect reasons such as acetone's volatile, low density, and not dissolving in water in the drawings that were coded as incorrect. This case brings up two different arguments in particular. First of all, PPSTs have a contradiction in the concept of homogeneous mixture due to the volatile nature of acetone. Another incorrect explanation that appears once again is that the pre-service teachers consider homogeneous and heterogeneous mixtures depending on the density. Apart from this, some pre-service teachers who had incorrect drawings thought of the question at the macroscopic level and could not draw on the basis of the explanation that the acetone-water mixture seemed like a single phase.

Table 4

The drawing levels and statements of the PPSTs related to particles' movements of acetone-water mixture

\begin{tabular}{|c|c|c|c|}
\hline Levels & fand $\%$ & Statements & $f$ \\
\hline Correct drawing & $4(5.1 \%)$ & $\begin{array}{l}\text { Since it dissolves, water and acetone molecules will be } \\
\text { attracted to form a bond. }\end{array}$ & 4 \\
\hline \multirow[t]{7}{*}{$\begin{array}{l}\text { Partially correct } \\
\text { drawing }\end{array}$} & \multirow[t]{7}{*}{$46(58.2 \%)$} & $\begin{array}{l}\text { It appears in a single phase as it dissolves into each } \\
\text { other. }\end{array}$ & 11 \\
\hline & & $\begin{array}{l}\text { Since it is a homogeneous mixture, the particles are } \\
\text { evenly spread throughout the mixture. }\end{array}$ & 9 \\
\hline & & $\begin{array}{l}\text { Since a homogeneous mixture is formed, the particles } \\
\text { are adjacent like a compound. }\end{array}$ & 8 \\
\hline & & $\begin{array}{l}\text { Since it is a homogeneous mixture, the particles are } \\
\text { very close to each other. }\end{array}$ & 6 \\
\hline & & $\begin{array}{l}\text { Since it is a homogeneous distribution, the particles } \\
\text { appear separate from each other. }\end{array}$ & 5 \\
\hline & & $\begin{array}{l}\text { There are no molecular interactions between acetone } \\
\text { and water molecules. }\end{array}$ & 4 \\
\hline & & $\begin{array}{l}\text { There are acetone molecules around the water } \\
\text { molecules. }\end{array}$ & 3 \\
\hline \multirow[t]{4}{*}{$\begin{array}{l}\text { Incorrect } \\
\text { drawing }\end{array}$} & \multirow[t]{4}{*}{$29(36.7 \%)$} & $\begin{array}{l}\text { Since acetone is volatile, acetone molecules are located } \\
\text { on the top of the water molecules. }\end{array}$ & 9 \\
\hline & & $\begin{array}{l}\text { Since the density of the water molecule is high, } \\
\text { acetone molecules are located on the top of the water } \\
\text { molecules. }\end{array}$ & 8 \\
\hline & & $\begin{array}{l}\text { Since acetone is not soluble in water, its particles stay } \\
\text { separately on the water molecules like oil. }\end{array}$ & 6 \\
\hline & & $\begin{array}{l}\text { It looks like a single phase since they are intermixed } \\
\text { within on another and cannot be distinguished by the } \\
\text { eye. }\end{array}$ & 6 \\
\hline
\end{tabular}


The next question (4th) that the PPSTs were asked: "What would you expect to happen when the thermometer shows $56^{\circ} \mathrm{C}$ ? This question was mainly intended to understand how the pre-service teachers explain the phenomenon occurring in the mixture at $56{ }^{\circ} \mathrm{C}$ according to the chemical representation levels by giving the boiling point of acetone. As seen in Figure 5, the majority of them had incorrect answers.

Figure 5

PPSTs' responses to the 4th question presented with their frequency and percentage distribution by categories

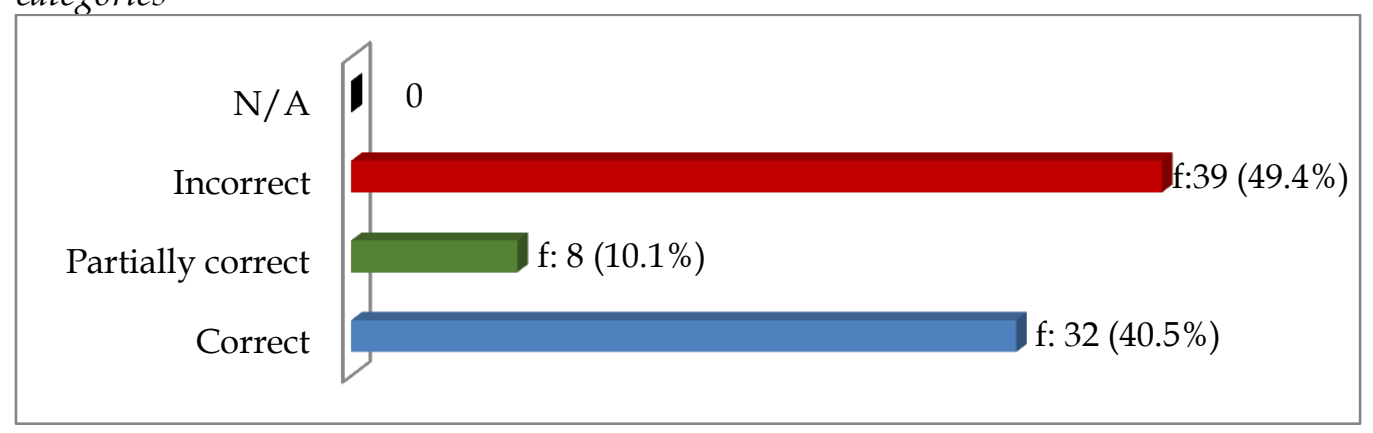

To consider the results of the analyses in terms of chemical representation levels, we found that most of the relevant statements were at the macroscopic level and only a few of them were at the sub-microscopic level. Although the statements of the pre-service teachers corresponded to the levels of representation, it was determined that the majority of their statements included scientifically incorrect responses (see Table 5). For instance, a significant number of them stated that acetone began to evaporate at $56^{\circ} \mathrm{C}$. This finding revealed clearly that the pre-service teachers did not have the knowledge that liquids evaporated at all temperatures. When we examined the other incorrect explanations at the macroscopic level, these statements were that acetone had a boiling point of $56^{\circ} \mathrm{C}$ since acetone was an alcohol and it began to evaporate at this point. Since the PPSTs considered acetone and alcohol as the same substances due to their volatility, this finding was both interesting and remarkable. In some explanations, it was stated that there was no evaporation in the acetone-water mixture at $56^{\circ} \mathrm{C}$, and evaporation or boiling occured at $100{ }^{\circ} \mathrm{C}$. Such incorrect thoughts may be due to the presence of water in the mixture. Apart from these statements, the explanation for the evaporation of the particles of acetone was one of the correct explanations at the submicroscopic level.

Table 5

The results of the analyses of the PPSTs' responses to the 4th question

\begin{tabular}{|c|c|c|c|}
\hline $\begin{array}{l}\text { Representation } \\
\text { Levels }\end{array}$ & Statements & $\begin{array}{l}\text { Accuracy } \\
\text { Levels }\end{array}$ & $f$ \\
\hline \multirow[t]{7}{*}{ Macroscopic } & Acetone begins to evaporate at $56^{\circ} \mathrm{C}$. & Incorrect & 30 \\
\hline & $\begin{array}{l}\text { Acetone changes state and separates from the mixture. Because the } \\
\text { boiling point of acetone is } 56^{\circ} \mathrm{C} \text {. }\end{array}$ & Correct & 22 \\
\hline & Since the boiling point of water is $100^{\circ} \mathrm{C}$, only acetone evaporates. & $\begin{array}{l}\text { Partially } \\
\text { correct }\end{array}$ & 8 \\
\hline & $\begin{array}{l}\text { A physical phenomenon occurs and the acetone evaporates } \\
\text { completely and only the water remains in the beaker. }\end{array}$ & Correct & 6 \\
\hline & $\begin{array}{l}\text { Since acetone is alcohol, its boiling point is lower, so at } 56{ }^{\circ} \mathrm{C} \text { the } \\
\text { temperature it remains constant and the alcohol begins to evaporate. }\end{array}$ & Incorrect & 4 \\
\hline & $\begin{array}{l}\text { The temperature of the acetone-water mixture increases, however } \\
\text { evaporation is not observed. Because evaporation occurs at } 100{ }^{\circ} \mathrm{C} \text {. }\end{array}$ & Incorrect & 3 \\
\hline & $\begin{array}{l}\text { The acetone-water mixture begins to heat, but does not boil. Because } \\
\text { water boils at } 100^{\circ} \mathrm{C} \text {. }\end{array}$ & Incorrect & 2 \\
\hline $\begin{array}{l}\text { Sub- } \\
\text { microscopic }\end{array}$ & $\begin{array}{l}\text { The particles of acetone evaporate and rise up through the } \\
\text { distillation flask. }\end{array}$ & Correct & 4 \\
\hline
\end{tabular}


In the 5th question, the PPSTs were asked to answer which substance to be separated from the mixture first and to explain the reasoning of their statements. Figure 6 shows that more than half $(67.1 \%)$ of them had scientifically correct responses, while those with incorrect responses accounted only for $24.0 \%$.

Figure 6

PPSTs' responses to the 5th question presented with their frequency and percentage distribution by categories

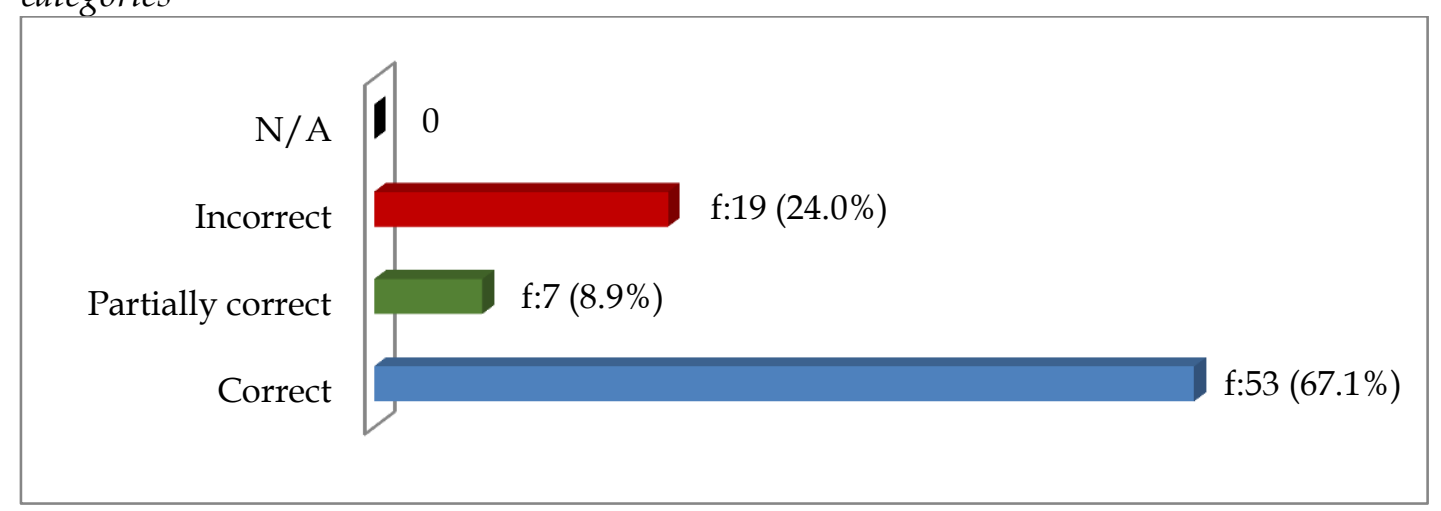

To give an example related to the macroscopic statements of the PPSTs, they stated that acetone with the lowest boiling point would be separated from the mixture first (See Table 6). Although the preservice teachers stated that acetone was the first substance to be separated from the mixture, they suggested the reasons such as acetone being volatile, low density, and alcohol in it. This fact indicates that they do not understand the evaporation and boiling processes sufficiently. In this context, it can be said that the subject related to the states of matter and the physical phenomenon is learned superficially and not meaningfully.

Table 6

The results of the analyses of the PPSTs' responses to the 5th question

\begin{tabular}{|c|c|c|c|}
\hline $\begin{array}{l}\text { Representation } \\
\text { Levels }\end{array}$ & Statements & $\begin{array}{l}\text { Accuracy } \\
\text { Levels }\end{array}$ & $f$ \\
\hline \multirow[t]{5}{*}{ Macroscopic } & $\begin{array}{l}\text { It is acetone. Because its boiling point is lower than } \\
\text { water. }\end{array}$ & Correct & 53 \\
\hline & It is acetone. Because acetone is volatile. & Incorrect & 9 \\
\hline & It is acetone. Because it evaporates faster than water. & $\begin{array}{l}\text { Partially } \\
\text { correct }\end{array}$ & 7 \\
\hline & It is acetone. Because its density is lower than water. & Incorrect & 6 \\
\hline & It is acetone. It evaporates quickly as it contains alcohol. & Incorrect & 4 \\
\hline
\end{tabular}

Another question (6th question) we asked the PPSTs was "How does the flow of the gas molecules in the glass tube of the Liebig condenser? Show it by drawing on the given figure". The main purpose of this question was to enable the PPSTs to illustrate how the particles of matter that reached the Liebig condenser behaved as they moved through the condenser, and by this way, to determine their submicroscopic levels. Examining the results of the pre-service teachers' drawings in Table 7, we determined that $41.8 \%$ were correct, $44.3 \%$ were partially correct and $13.9 \%$ were incorrect drawings. In partially correct drawings, the distances between acetone molecules in the condenser were generally equally spaced. In some drawings, the particles were shown at the top and the end of the condenser and the flow of the particles through the condenser were not shown. Some of the PPSTs who had the incorrect drawings showed that the particles in the gas state were close to each other and the distance between the particles increased as they moved through the condenser (see Figure 7). Apart from this, the PPSTs who had partially correct and incorrect drawings thought 
that only acetone molecules were concentrated; however, they could not imagine that the water molecules also evaporated and condensed, even if only a little. This is because they do not know that the distillation technique used to separate liquid-liquid mixtures should be applied more than once.

Figure 7

Sample drawings of the pre-service teachers in the 6th question

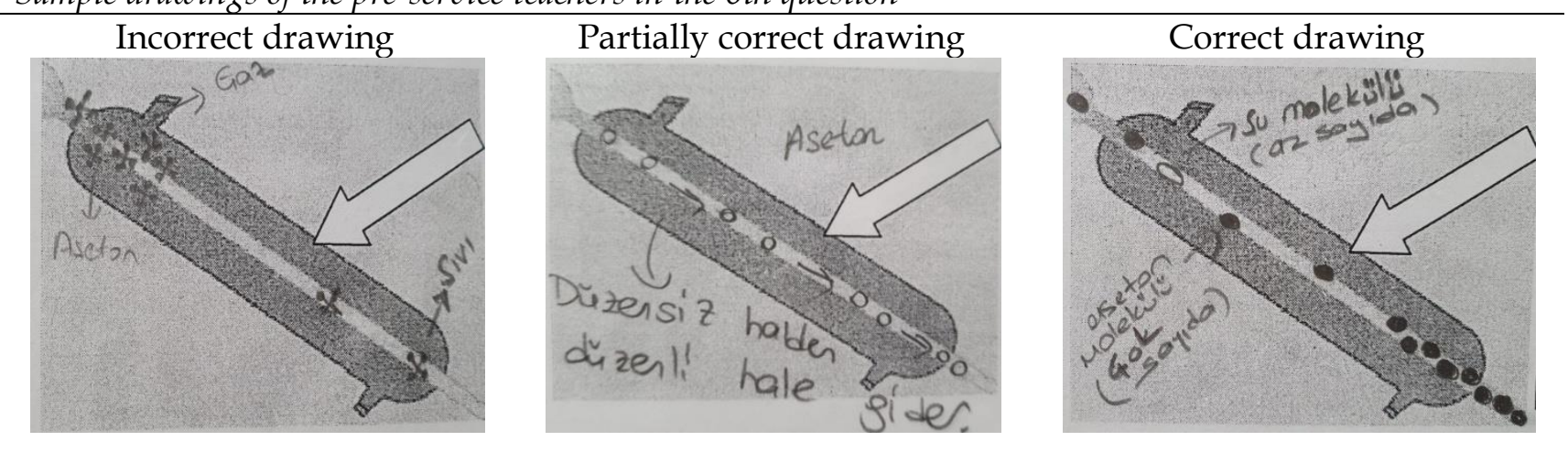

Table 7

The drawing levels and statements of the PPSTs related to particles' movements in the Liebig condenser

\begin{tabular}{|c|c|c|c|}
\hline $\begin{array}{l}\text { Levels } \\
\text { Correct drawing }\end{array}$ & fand $\%$ & Statements & $f$ \\
\hline \multirow[t]{3}{*}{ Correct drawing } & $33(41.8 \%)$ & $\begin{array}{l}\text { The gas acetone changes into a liquid phase } \\
\text { with cold water and drops into a beaker. }\end{array}$ & 16 \\
\hline & & $\begin{array}{l}\text { The gas condenses. While the molecules are } \\
\text { more irregular at first, they become more } \\
\text { regular towards the end of the condenser. }\end{array}$ & 13 \\
\hline & & $\begin{array}{l}\text { At first, the distance between the particles is } \\
\text { great; cooling brings them a little closer } \\
\text { together. }\end{array}$ & 4 \\
\hline Partially correct & $35(44.3 \%)$ & The gas acetone changes phase into liquid form & 23 \\
\hline
\end{tabular}

drawing

in the condenser.

Acetone molecules enter the condenser 12 irregularly, but the particles approach each other as they move through the condenser.

\begin{tabular}{llll}
\hline Incorrect drawing $\quad 11(13.9 \%)$ & At first, the gas acetone and the gas water & 9 \\
& molecules enter together. Only acetone \\
& molecules come out of the condenser and are \\
& collected in the container. \\
& It changes from condensation to sublimation. & 2
\end{tabular}

When the statements of the pre-service teachers on their drawings were examined, some of them who made the correct drawings gave answers at the macroscopic level by stating that the acetone in the gas state became liquid with the water in the condenser and dropped into a beaker (see Table 7). Some PPSTs who gave correct responses also made statements at the sub-microscopic level and stated that the irregular molecules became more regular towards the end of the condenser. Similar correct statements were found at the macroscopic and sub-microscopic levels in those who gave partially correct responses; however, they could not reflect this in their drawings accurately. A remarkable result emerges in drawings coded as incorrect drawings. Most of the PPSTs who had incorrect drawings stated that only acetone molecules among the evaporating acetone and water molecules passed through the condenser and collected in the beaker. This might be due to the fact that they thought 
that the separation takes place by considering only the function of the condenser, not all of the stages of the distillation technique.

When we examined the responses to the 7th question "Which substances are found in glass materials indicated by arrows at the end of the distillation experiment? Explain your reasons by writing in the white boxes", we found that $51.9 \%$ of the pre-service teachers answered partially correct and $44.3 \%$ of them answered incorrectly (see Figure 8 ). From this point of view, we can say that PPSTs know the distillation experiment as a separation method. However, they thought that the mixture was separated using this separation technique at once. However, in the distillation process, the separation of liquid-liquid mixtures such as acetone-water occurs by following it several times. In this case, the PPSTs ignored that liquids evaporate at any temperature.

Figure 8

PPSTs' responses to the 7th question presented with their frequency and percentage distribution by categories

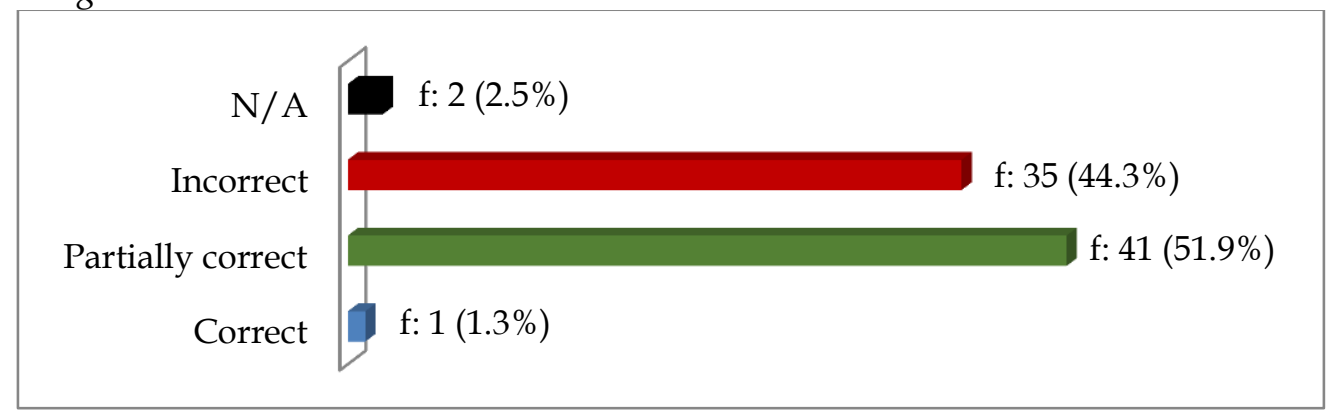

Considering the statements given by the PPSTs regarding the reason of question 7 about the substances in the containers after the distillation process, we found more statements at the macroscopic level similar to the other results. For example, a great number of pre-service teachers stated that water did not evaporate at any temperature because its boiling point was $100{ }^{\circ} \mathrm{C}$ and only acetone was collected in the container at the end of the experiment (see Table 8). The PPSTs who responded partially correct stated that due to the acetone has a lower boiling point than water, only acetone could be collected in the container. However, even though acetone was collected in the beaker, a very little amount of water evaporated, so it remained in the container. Therefore, these statements indicate that the PPSTs cannot exactly realize the distillation technique and evaporation. Apart from this, statements including particle size that we could not perceive with our sensory organs were encountered and we determined that these PPSTs gave partially correct responses.

At the end of the experiment, in question 8, where we asked them to write the chemical formulas of the substances in the flask and beaker, $40.5 \%$ of the pre-service teachers wrote both formulas correctly, while $53.2 \%$ could only write the chemical formula of water, but not that of acetone (see Figure 9). Although this finding was expected from PPSTs, it was quite surprising that most of them wrote the formula for an alcohol instead of acetone. Parallel to the similar results, the PPSTs confused the formula of acetone with the formula of methyl alcohol or ethyl alcohol that might be due to the fact that the boiling points of these substances were lower than water and their physical properties such as volatility were similar. 
Table 8

The results of the analyses of the PPSTs' responses to the 7th question

\begin{tabular}{|c|c|c|c|}
\hline $\begin{array}{l}\text { Representation } \\
\text { Levels }\end{array}$ & Statements & $\begin{array}{l}\text { Accuracy } \\
\text { Levels }\end{array}$ & $f$ \\
\hline \multirow[t]{4}{*}{ Macroscopic } & $\begin{array}{l}\text { Since acetone has a lower boiling point, acetone is } \\
\text { collected in the beaker. }\end{array}$ & $\begin{array}{l}\text { Partially } \\
\text { correct }\end{array}$ & 36 \\
\hline & $\begin{array}{l}\text { Since the boiling point of water is } 100{ }^{\circ} \mathrm{C} \text {, it does not } \\
\text { evaporate. Therefore, only acetone evaporates and } \\
\text { becomes vapor, and then it is collected in the beaker. }\end{array}$ & Incorrect & 24 \\
\hline & $\begin{array}{l}\text { When the thermometer reaches } 56^{\circ} \mathrm{C} \text {, acetone begins } \\
\text { to evaporate; the water remains in the flask. }\end{array}$ & Incorrect & 11 \\
\hline & $\begin{array}{l}\text { Both water and acetone are collected in the beaker as } \\
\text { both substances evaporate at any } \\
\text { temperature.However, since the boiling point of } \\
\text { acetone is } 56^{\circ} \mathrm{C} \text {, the amount of acetone in the beaker is } \\
\text { more. }\end{array}$ & Correct & 1 \\
\hline $\begin{array}{l}\text { Sub- } \\
\text { microscopic }\end{array}$ & $\begin{array}{l}\text { There is acetone in the beaker, as it is the acetone } \\
\text { molecules that are the first separated ones. }\end{array}$ & $\begin{array}{l}\text { Partially } \\
\text { correct }\end{array}$ & 5 \\
\hline
\end{tabular}

Figure 9

PPSTs' responses to the 8th question presented with their frequency and percentage distribution by categories

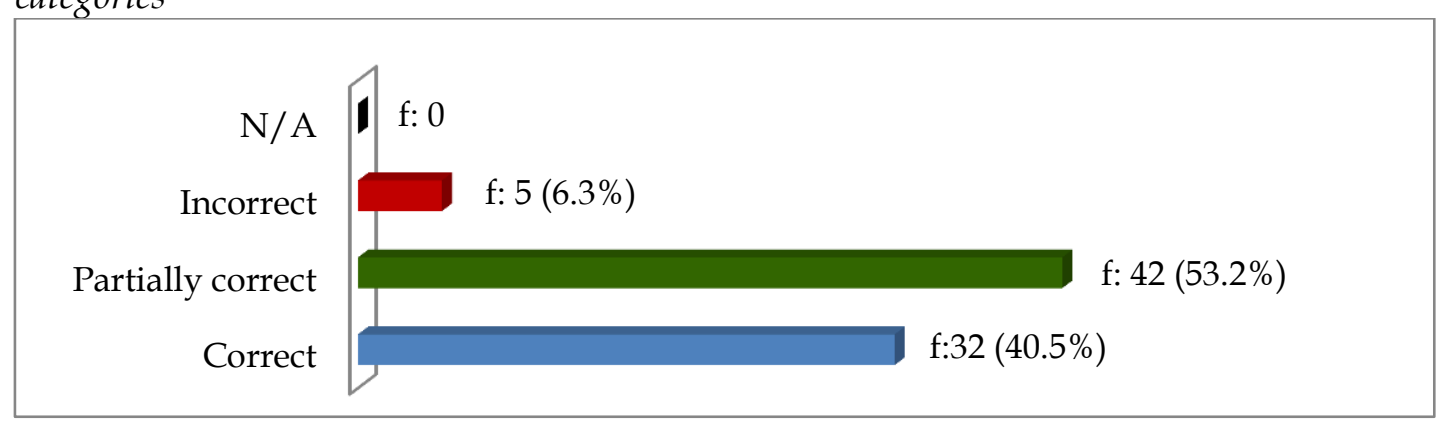

Finally, the 9th question "What would you expect if methylated spirits consisting of methyl alcohol and water were used as a distillation mixture in this experiment?" was asked to the PPSTs to comment on the separation of that mixture, which can be separated into its components by distillation technique and is more common in daily life. As can be seen in Figure 10, most of the PPSTs had difficulties in answering this question. There was only $38.0 \%$ of the pre-service teachers gave the correct answers to the question.

Figure 10

PPSTs' responses to the 9th question presented with their frequency and percentage distribution by categories

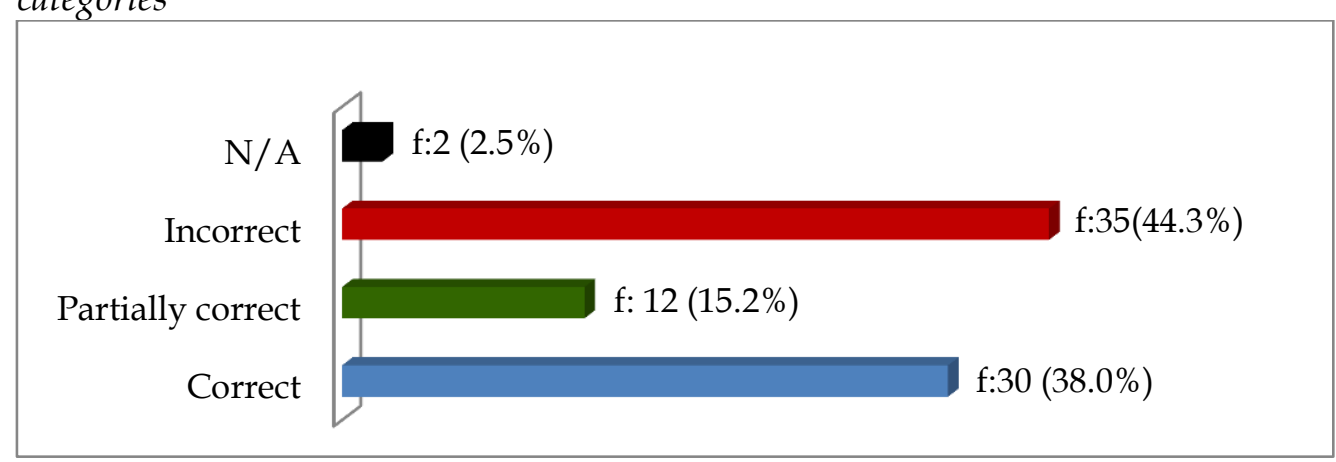


The pre-service teachers gave responses at the macroscopic level in their statements about the 9 th question on chemical representation levels. As seen in Table 9, although some responses to the question with scientific accuracy, there were PPSTs with various misunderstandings and miscomprehension. For example, although it is a mixture that is frequently encountered, they could not predict the boiling points of water and methyl alcohol, they expressed that methyl alcohol dissolved the paint it contained and then left the solution together with the paint, and also they stated methylated spirit had a boiling point and compared this point with that of water according to these assumptions that the substance separated might change.

Table 9

The results of the analyses of the PPSTs' responses to the 9th question

\begin{tabular}{|c|c|c|c|}
\hline $\begin{array}{l}\text { Representation } \\
\text { Levels }\end{array}$ & Statements & Accuracy Levels & $f$ \\
\hline \multirow[t]{7}{*}{ Macroscopic } & $\begin{array}{l}\text { Since the boiling point of methyl alcohol is lower } \\
\text { than water, methyl alcohol was separated first. }\end{array}$ & Correct & 30 \\
\hline & $\begin{array}{l}\text { Water evaporates first, then methyl alcohol. } \\
\text { Because the boiling point of methyl alcohol is } \\
\text { higher than water. }\end{array}$ & Incorrect & 13 \\
\hline & $\begin{array}{l}\text { Since methyl alcohol is a volatile substance, it } \\
\text { would be separated first. }\end{array}$ & Partially correct & 12 \\
\hline & $\begin{array}{l}\text { I would expect the methyl alcohol to dissolve the } \\
\text { paint in the methylated spirits. Together with the } \\
\text { paint, the methyl alcohol was separated from the } \\
\text { mixture. }\end{array}$ & Incorrect & 7 \\
\hline & $\begin{array}{l}\text { The boiling point of water is lower than that of } \\
\text { methylated spirits. Therefore, the water would } \\
\text { evaporate first. }\end{array}$ & Incorrect & 6 \\
\hline & $\begin{array}{l}\text { Since the boiling point of methylated spirits is } \\
\text { different from water, the substance collected in the } \\
\text { beaker may change. }\end{array}$ & Incorrect & 5 \\
\hline & $\begin{array}{l}\text { The mixture has a boiling point. Therefore, the } \\
\text { substances that first separated from the mixture } \\
\text { would change. }\end{array}$ & Incorrect & 4 \\
\hline
\end{tabular}

These remarkable results indicate that the PPSTs cannot consider the mixtures apart from the physical properties of the pure substances. At the same time, based on the results, we can infer that the pre-service teachers have problems in adapting what they know when they encounter different situations and that the alcohol-water mixture is homogeneous and they do not soundly comprehend the function of the distillation technique in the separation of liquid-liquid homogeneous mixtures.

\section{Discussion and Conclusion}

Chemistry, which is a field of science that forms the basic scope of this research and has had a profound effect on all scientific development, is one of the most fundamental discipline. Since chemistry subjects are generally related to the internal structure of matter, they also require students to learn abstractly (Paik et al., 2004). For this reason, chemistry is quite complex and difficult to understand for students. Primary school students encounter science concepts for the first time in the "Social Studies" course, and in real terms, in the 3rd, 4th and 5th grades of primary schools. Because of this, primary school teachers have a great responsibility in teaching at these grades in order to prevent misunderstandings that will reflect negatively on their further learning (Banawi et al., 2019; Birinci Konur \& Ayas, 2008). In this study, an application was carried out to improve both theoretical and practical chemistry knowledge of pre-service teachers who will 
become primary school teachers in the future. When the results of the research were examined, misunderstandings were mostly encountered in the basic chemistry knowledge of the pre-service teachers.

As a crucial research result, we came across the PPSTs' inability to recognize chemical substances. The pre-service teachers expressed the acetone used in the distillation experiment as alcohol. This result shows that the PPSTs do not have knowledge related to the chemical and physical properties, symbolic representations, molecular structures of the substances, and moreover, they confuse the acetone is same as the alcohol substance due to a physical property such as volatility. In parallel with this result, many studies have identified that primary pre-service teachers had difficulties in recognizing substances in terms of their chemical and physical properties (Banawi et al., 2019; Karaer, 2007; Mete, 2020; Valanides, 2000). These misunderstandings that pre-service teachers have may reflect adversely on their students who will be informed about Matter and its properties for the first time in primary education (Lin et al., 2000; Valanides, 2000). Moreover, it may become increasingly difficult to correct these misunderstandings in further learning (Horton, 2007; Valanides, 2000). As a result of all these reasons, pre-service teachers should learn the macroscopic, sub-microscopic, and symbolic chemical representations in order to be able to describe the matters correctly and understand their properties. Sub-microscopic representations tend to be ignored in chemistry education due to the limitation of the learning at the macroscopic level and symbolic level (Lindawati et al., 2019). Tania and Fadiawati (2015) stated that the lack of representations at the sub-microscopic level may obstruct the ability of students to perceive chemical phenomena and their ability to solve problems related to macroscopic phenomena. Therefore, with the help of video activities such as animations, which are also used in the present study, the proficiency of pre-service teachers at this representation level can be improved.

Even though the PPSTs more accurately stated in their macroscopic statements that acetone could be used to dissolve nail polish, the results of the research indicated that the pre-service teachers were also quite inadequate in this sense because they could not illustrate the symbolic representation of acetone, although it is a frequently used chemical substance in our daily life, or wrote the chemical formula of any alcohol instead. This situation also reveals that pre-service teachers could not establish a relationship between macroscopic and symbolic representations. However, in order to successful learning in chemistry it is necessary to form an accurate construction of the mental relationship between the macroscopic, sub-microscopic, and symbolic levels and to use these levels together in the representations of scientific phenomena (Cheng \& Gilbert, 2009; Chittleborough \& Treagust, 2007; Sunyono et al., 2015). On account of this fact, it can be ensured that these inadequacies can be overcome easily by giving examples at these representation levels in the teaching of basic chemistry subjects to pre-service teachers.

In addition, the results demonstrated that the pre-service teachers thought that the acetonewater mixture was a heterogeneous mixture and they stated that acetone would be placed on the top due to the difference in density in the mixture. This situation indicates that the PPSTs have lack of theoretical knowledge about the mixtures and dissolution. In accordance with this result, it was stated that pre-service teachers had difficulties in basic chemistry subjects such as mixtures and solubility principles (Çalık et al., 2009; Papageorgiou \& Sakka, 2000; Papageorgiou et al., 2010; 2013; Phiri, 2008). In addition to this, this situation may be due to the insufficient laboratory experience of the pre-service teachers as well as the inadequacy of them in the subject of mixtures. It is possible to learn in the laboratory by manipulating the necessary equipment and materials to construct students' knowledge of scientific phenomena and related scientific concepts (Abrahams \& Millar, 2008). For this reason, laboratory education is required in the curriculum adequately so that the students can collect key information, make accurate observations, ask questions, and make connections to useful knowledge (Akkuzu \& Uyulgan, 2017). Pre-service primary school teachers make practical applications in the "Science and Technology Laboratory Applications" course within the renewed four-year primary education program (CoHE, 2018). It will be beneficial to increase the 
frequency of the applications in this course and to support these applications with the most creative technologies such as animation and simulation in order to understand the particle size distribution. In her study, Wishart (2017) pointed out that the pre-service primary school teachers perceived benefits of making animation in school science, enabled their pupils to be creative, and pointed out that it enables teachers to challenge and interest pupils in science. It can be considered that pre-service teachers perceived the dissolution phenomenon only macroscopically as well. In their correct statements, the PPSTs were able to state that acetone and water would form a homogeneous mixture, mostly with their observable properties. We can also reveal that most of them who gave partially correct responses could not demonstrate the interactions between solvent and solute molecules at the sub-microscopic level during molecular dissolution. Additionally, although most of the pre-service teachers expressed that acetone and water were a homogeneous mixture, they made many incorrect statements about particle size. This result appears more clearly in the statements of the pre-service teachers who could not express that it was a homogeneous mixture and who drew incorrectly. All these results indicate that pre-service teachers could not think at the sub-microscopic level and could not completely relate with the physical changes they observe at this level. However, many studies suggested that students should be able to establish a link between their knowledge of sub-microscopic representation with the macroscopically observed phenomenon for building a scientific understanding of the nature of dissolution (Adadan, 2014; Ainsworth, 2006; Chiu, 2007; Daubenmire, 2014; Mayer, 2009).

Another result in the current study was that the majority of statements of the pre-service teachers include scientifically incorrect responses related to evaporation and boiling phenomena. For instance, they have the idea that "evaporation begins at boiling point". This result shows that the pre-service teachers do not have the knowledge that liquids evaporate at all temperatures. Although also a few of them have this knowledge it implies that they are unable to explain the knowledge they have acquired in science classes in novel situations which require them to analyze or synthesize. Similarly, in the study of Valanides (2000) based on primary student teachers' understanding of the process and effects of distillation, pre-service teachers were unable to differentiate between boiling and evaporation. Also according to his results, they believed that "the liquid will start "evaporating" at a certain temperature". Similar finding appears in their study of Canpolat et al. (2006). Their study reflected the general view that pre-service teachers confused that vaporization and boiling phenomena. This may be because they have non-science backgrounds based on their daily life practices and an inadequate knowledge of science (Şenocak, 2009). Another remarkable result of our study is that the pre-service teachers consider acetone and alcohol as the same substance due to their volatility. They believe that evaporation occurs due to its volatility. In addition to this, they have the idea that "the acetone-water mixture does not boil until the boiling point of water". This implies that they could not distinguish between the properties of the mixture and the pure substance. Similarly, in another question regarding the distillation of methylated spirit, which is frequently encountered in daily life, it was revealed that some preservice teachers perceived methylated spirit as a compound and claimed that it had a boiling point as if it was a pure substance. This result shows that the pre-service teachers could not distinguish basic concepts such as pure substance-mixture, compound-mixture from each other. Likewise, Karaer (2007) stated in his study that pre-service teachers made incorrect expressions related to the concepts of element-compound, element-pure substance, element-mixture, compound-pure substance, compound-mixture, homogeneous-heterogeneous mixture, and dissolution-dissolution.

Considering our research results, we encounter an important clue that reflects the reason for this case. As it is taken into consideration, it has been determined that most of the pre-service teachers' statements were frequently at the macroscopic level. However, using the macroscopic language causes many problems in understanding basic chemistry subjects (Meijer, 2011; Piquette \& Heikkinen, 2005). Failure to establish a relationship between macroscopic and sub-microscopic levels causes invisible phenomena to be explained, the process of the analysis and synthesis to not function properly and therefore scientific knowledge cannot be learned completely and accurately. 
To avoid these problems there should be multiple representations related to the molecular view of matter for understanding of the properties and classifications of matter and physical change of the matter such as evaporation (Adadan, 2014; Tytler et al., 2007). As it is known, these are the fundamental subjects of science taught from the primary school onwards. PPSTs should be able to establish the connection between chemical representations in order to have a basic and scientific quality on these issues related to daily life.

In this study in which the distillation experiment was carried out, although the pre-service teachers followed the stages of distillation, they had some difficulties answering the questions about certain stages. As known, distillation is related to several physical changes, such as evaporation, boiling, and vapour condensation. Another part of the distillation experiment that pre-service teachers had difficulty with was the vapour condensation stage. Here, we asked the pre-service teachers related to the movements of the particles. When we examined the difficulties faced by the pre-service teachers, we found that they could not show the condensed particles throughout the condenser, they drew the water and acetone vapours close to each other at the beginning and showed the distances between the particles of the condensed acetone equal intervals or dispersed. This result indicates that the pre-service teachers could not predict how the intermolecular interaction changes during the condensation and the distance between the particles. Also, it shows that they could not establish a relationship between the particulate nature of matter and the connection between the observable macroscopic changes (i.e., condensation and evaporation) and the way molecules move in relation to one another, and how they are held together. As asserted in previous studies, condensation and evaporation include invisible gas state changes (Bar \& Galili, 1994; Paik et al., 2004; Tytler, 2000), so it is difficult to say that pre-service teachers explain these phenomena with scientific accuracy until they are able to think from a microscopic point of view in this operational stage. However, it is stated that various simulations of particle behaviour can be developed in order to better understand particulate nature of substances. Considering the results of the research in general, it is quite obvious that the basic chemistry knowledge of the PPSTs about daily life including the substance and its physical phenomena is insufficient. Results revealed from the worksheets support the idea that PPSTs have a limited understanding of the particulate nature of matter and the relation of observable macroscopic changes. In this regard, it can be said that pre-service teachers could not learn basic chemistry concepts, facts, and phenomena accurately and permanently before their undergraduate education. In order to prevent this lacking from being reflected in primary school students, it is very necessary and crucial for pre-service primary school teachers to be well educated about basic science subjects in both theoretical and practical terms (Papageorgiou et al., 2010; 2013). By this research, PPSTs were provided with a learning environment where they could explain the nature of chemical substances and phenomena related to daily life, and the opportunity to obtain experience in science subjects was also created.

\section{Recommendations}

There have been some recommendations developed based on the results herein and the relevant literature:

- For researchers more studies should be conducted on whether both primary school students and pre-service primary school teachers have misunderstandings in the basic chemistry subjects in the renewed primary education program (especially at the 3rd, 4th, and 5th grades) and what these understandings are.

- Not only higher-level students but also elementary school students must understand physical phenomena, although it is difficult to introduce the microscopic point of view to elementary school students. Therefore, various approaches using multiple representations are needed to develop an understanding of fundamental science subjects in the primary school teachers who will be teachers of primary school students. 
- Considering the results of this study about the inadequacy of the pre-service teachers in sub-microscopic representations, it can be ensured that these representations are included more in the teaching of basic chemistry subjects. In addition, as in this study, well-planned teaching activities in which the relationship between all chemical representation levels are explained aside from macroscopic definitions in chemistry subjects related to daily life can be carried out.

- Projects, workshops, applications, etc. in which the PPSTs will be more active in basic chemistry subjects in laboratory experiments related to daily life can be organized with them.

- In in-service training, chemistry experiment design and application activities can be organized with primary school teachers at a basic level, which they can perform with daily life tools and equipment. Such activities can be supported by instructional software that includes demonstrations regarding the internal structure of matter.

\section{References}

Abrahams, I., \& Millar, R. (2008). Does practical work really work? A study of the effectiveness of practical work as a teaching and learning method in school science. International Journal of Science Education, 30(14), 1945-1969. https://doi.org/10.1080/09500690701749305

Adadan, E. (2014). Investigating the influence of pre-service chemistry teachers' understanding of the particulate nature of matter on their conceptual understanding of solution chemistry. Chemistry Education Research and Practice, 15(2), 219-238. https:// doi.org/10.1039/c4rp00002a

Ainsworth, S. (2006). DeFT: A conceptual framework for considering learning with multiple representations. Learning and Instruction, 16(3), 183-198. https:// doi.org/10.1016/j.learninstruc.2006.03.001

Akkuzu, N., \& Uyulgan, M. A. (2017). Step by step learning using the I diagram in the systematic qualitative analysis of cations within a guided inquiry learning approach. Chemistry Education Research and Practice, 18(4), 641-658. https://doi.org/10.1039/C7RP00050B

Alkan, F. (2016). Experiential learning: Its effects on achievement and scientific process skills. Journal of Turkish Science Education, 13(2), 15-26. https:/ / doi.org/10.12973/tused.10164a

Anderson, D., Bartholomew, R., \& Moeed, A. (2009, September 2-5). Confidence, knowledge and teaching strategies: A study of pre-service science teachers in a New Zealand university [Paper presentation].British Educational Research Association Annual Conference, University of Manchester, England. http://www.leeds.ac.uk/educol/documents/187731.pdf

Appleton, K. (2007). Primary science teaching. In S. K. Abell \& N. G. Lederman (Eds.), Handbook of research on science education (pp. 493-535). Lawrence Erlbaum.

Banawi, A., Sopandi, W., Kadarohman, A., \& Solehuddin, M. (2019). Prospective primary school teachers' conception change on states of matter and their changes through Predict-Observe-Explain Strategy. International Journal of Instruction, 12(3), 359-374. https:// doi.org/10.29333/iji.2019.12322a

Bar, V., \& Galili, I. (1994) Stages of children's views about evaporation. International Journal of Science Education, 16, 157-174. https://doi.org/10.1080/0950069940160205

Birinci Konur, K., \& Ayas, A. (2008). The level of understanding of class teacher candidates' some chemistry concepts. Kastamonu Education Journal, 16(1), 83-90.

Canpolat, N., Pınarbaşı, T., \& Sözbilir, M. (2006). Prospective teachers' misconceptions of vaporization and vapor pressure. Journal of Chemical Education, 83(8), 1237-1242. https://doi.org/10.1021/ed083p1237

Capps, D. K., Crawford, B. A., \& Constas, M. A. (2012). A review of empirical literature on inquiry professional development: Alignment with best practices and a critique of the findings. Journal of Science Teacher Education, 23(3), 291-318. https:/ / doi.org/10.1007/s10972-012-9275-2

Charles, C. M. (2000). Öğretmenler için Piaget ilkeleri [Teacher's petit Piaget] (G. Ülgen, Trans.). PegemA. (Original work published in 1974).

Cheng, M., \& Gilbert, J. K. (2009). Towards a better utilization of diagrams in research into the use of representative levels in chemical education. In J. K. Gilbert \& D. F. Treagust (Eds.), Multiple Representations in Chemical Education (pp.55-73). Springer. 
Chittleborough, G. D., \& Treagust D.F. (2007). The modelling ability of non-major chemistry students and their understanding of the sub-microscopic level. Chemistry Education Research and Practice, 8(3), 274-292. https://doi.org/10.1039/B6RP90035F

Chiu, M-H. (2007). A national survey of students' conceptions of chemistry in Taiwan. International Journal of Science Education, 29(4), 421-452. https:// doi.org/10.1080/09500690601072964

Connelly, L. M. (2016).Cross-sectional survey research. MedSurg Nursing, 25(5), 369-370.

Corradi, D., Elen, J., \& Clarebout, G. (2012). Understanding and enhancing the use of multiple external representations in chemistry education. Journal of Science Education and Technology, 21(6), 780-795. https://doi.org/10.1007/s10956-012-9366-z

Coştu, B., Ayas, A., Çalık, M., Ünal, S., \& Karataş, F. Ö. (2005). Determining preservice science teachers' competences in preparing solutions and in use of laboratory tools. Hacettepe University Journal of Faculty of Education, 28 (28), 65-72.

Çalık, M., Ayas, A., \& Coll, R. K. (2009). Investigating the effectiveness of an analogy activity in improving students' conceptual change for solution chemistry concepts. International Journal of Science and Mathematics Education, 7(4), 651-676. https://doi.org/10.1007/s10763-008-9136-9

Çeken, R. (2010a). The process of pre-service classroom teachers in science education from high school to university. Balikesir University the Journal of Social Sciences Institute, 12(22), 187-193.

Çeken, R. (2010b). A "Ballon Car" activity in Science and Technology Education. Elementary Education Online, 9(2), $1-5$.

Çepni, S. (2010). Araştırma ve proje çalışmalarna giriş [Introduction to research and project studies] (5th ed.). Ofset.

Daubenmire, P. L. (2014). Using multiple representations to resolve conflict in student conceptual understanding of chemistry [Unpublished doctoral dissertation]. University of California, Berkeley.

Davidowitz, B., \& Chittleborough, G. (2009). Linking the macroscopic and sub-microscopic levels: Diagrams. In J. K. Gilbert, and D. Treagust (Eds.), Models and modelling in science education: Multiple representations in chemical education (pp. 169-191). Springer, Netherlands.

Erduran, S. (2005). Applying the philosophical concept of reduction to the chemistry of water: Implications for chemical education. Science \& Education, 14, 161-171. https://doi.org/10.1007/s11191-005-0687-7

Ferreira, M. E., Porteiro A. C., \& Pitarma, R. (2015, July 6-8). Teaching science in primary education in an engineering laboratory. In 7th annual International Conference on Education and New Learning Technologies (Proceedings of EDULEARN15 Conference) (pp. 2313-2320). Barcelona.

Gobert, J. D., \& Buckley, B. C. (2000). Introduction to model-based teaching and learning. International Journal of Science Education, 22(9), 891-894. https://doi.org/10.1080/095006900416839

Güneş, B., Gülçiçek, Ç., \& Bağcl, N. (2004). Eğitim fakültelerindeki fen ve matematik öğretim elemanlarının model ve modelleme hakkındaki görüşlerinin incelenmesi [Examining the views of science and mathematics instructors in education faculties about modeling and modeling]. Journal of Turkish Science Education, 1(1), 35-48.

Hackling, M., Peers, S., \& Prain, V. (2007). Primary connections: Reforming science teaching science in Australian primary schools. Teaching Science, 53(3), 12-16.

Harlen, W. (2004). Evaluating inquiry-based science developments. National Research Council. http://www7.nationalacademies.org/bose/WHarlen_inquiry__Mtg_paper.pdf

Harrison, A. G., \& Treagust, D. F. (2000). A typology of school science models. International Journal of Science Education, 22(9), 1011-1026. https://doi.org/10.1080/095006900416884

Hodson, D. (2005). Towards research-based practice in the teaching laboratory. Studies in Science Education, 41(1), 167-177. https://doi.org/10.1080/03057260508560217

Hofer, S. M., Sliwinski, M. J., \& Flaherty, B. R. (2002). Understanding ageing: Further commentary on the limitations of cross-sectional designs for ageing research. Gerontology, 48(1), 22-29. https://doi.org/10.1159/000048920

Hofstein, A., Kipnis, M., \& Abrahams, I. (2013). How to learn in and from the chemistry laboratory. In I. Eilks \& A. Hofstein (Eds.), Teaching chemistry - A studybook: A practical guide and textbook for student teachers, teacher trainees and teachers (pp.153-182). Sense.

Horton, C. (2007). Student alternative conceptions in chemistry. California Journal of Science Education, 7(2), 18-38.

Karaer, H. (2007). Examination of student teachers' levels of understanding and misconceptions of some concepts about substance and determination regarding to some variables. Kastamonu Education Journal, 15(1), 199-210. 
Kennedy, D. (2013). The role of investigations in promoting inquirybased science education in Ireland. Science Education International, 24(3), 282-305.

Kidanemariam, D. A., Atagana, H. I., \& Engida, T. (2013). The place of philosophy of chemistry in reducing chemical misconceptions. African Journal of Chemical Education, 3(2), 106-117.

Lamanauskas, V. (2003). Natural science education in contemporary school. Siauliai University Press.

Lamanauskas, V. (2009). The importance of strengthening of natural science education in a primary school. Problems of Education in the 21st Century, 11, 5-8.

Lin, H-S., Cheng, H-J., \& Lawrenz, F. (2000). The assessment of students and teachers' understanding of gas laws. Journal of Chemical Education, 77(2), 235-238. https://doi.org/10.1021/ed077p235

Lindahl, B. (2003). Pupils' responses to school science and technology? A longitudinal study of pathways to upper secondary school. [Unpublished doctoral dissertation]. University of Gothenburg, Sweden.

Lindawati, L., Wardani, S., \& Sumarti, S. S. (2019). Development of inquiry materials based on chemical representation to improve students' critical thinking ability. Journal of Innovative Science Education, 8(3), 332-343. https:/ / doi.org/10.15294/JISE.V8I1.31082

Mahaffy, P. (2006). Moving chemistry education into 3D: A tetrahedral metaphor for understanding chemistry. Journal of Chemical Education, 83(1), 49-55. https:// doi.org/10.1021/ed083p49

Maltese, A. V., Melki, C. S., \& Wiebke, H. L. (2014). The nature of experiences responsible for the generation and maintenance of interest in STEM. Science Education, 98(6), 937-962. https://doi.org/10.1002/sce.21132

Mayer, R. E. (2009). Multimedia learning (2nd ed.). Cambridge University Press.

Meijer, M. R. (2011). Macro-meso-micro thinking with structure-property relations for chemistry education: An explorative design-based study [Unpublished doctoral dissertation]. Utrecht University, Netherlands.

Mete, P. (2020). Determination of primary school teachers' alternative frameworks regarding the concepts of melting of ice, density and solubility of gases in water. Journal of Science Teaching, 8(2), 121-142.

Miles, M. B., \& Huberman, A. M. (1994). Qualitative data analysis: An expanded sourcebook (2nd ed.). Sage.

Ministry of National Education [MoNE]. (2013). Illköğretim kurumlarn (ilkokullar ve ortaokullar) Fen Bilimleri dersi (3., 4., 5., 6., 7. ve 8. sinuflar) ögretim programı [Science course (3rd, 4th, 5th, 6th, 7th and 8th grades) curriculum of primary education institutions (Primary schools and secondary schools)]. http://ttkb.meb.gov.tr/www/guncellenen-ogretimprogramlari/icerik/151.

Nakhleh, M. B., Polles, J., \& Malina, E. (2002). Learning chemistry in a laboratory environment. In Gilbert J. K., De Jong O., Justi R., Treagust D. F. and Van Driel J. H. (Eds.), Chemical education: Towards research-based practice (pp. 69-94). Kluwer Academic Publishers.

National Research Council [NRC]. (2006). America's Lab Report: Investigations in High School Science. The National Academies Press. https://doi.org/10.17226/11311

Nilsson, P. (2008). Recognizing the needs: Student teachers' learning to teach from teaching. Nordic Studies in Science Education, 4(1), 284-299. https:// doi.org/10.5617/nordina.371

Osborne, J., \& Dillon, J. (2008). Science education in Europe: Critical reflections. The Nuffield Foundation.

Paik, S-H., Kim, H-N., Cho, B-K., \& Park, J-W. (2004). K-8th grade Korean students' conceptions of changes of state and conditions for changes of state. International Journal of Science Education, 26(2), 207-224. https://doi.org/10.1080/0950069032000052063

Papageorgiou, G., \& Sakka, D. (2000). Primary school teachers' views of fundamental chemical concepts. Chemistry Education: Research and Practice in Europe, 1(2), 237-247. https:/ / doi.org/10.1039/A9RP90025J

Papageorgiou, G., Stamovlasis, D., \& Johnson, P. M. (2010). Primary teachers' particle ideas and explanations of physical phenomena: Effect of an in-service training course. International Journal of Science Education, 32(5), 629-652. https:// doi.org/10.1080/09500690902738016

Papageorgiou, G., Stamovlasis, D., \& Johnson, P. (2013). Primary teachers' understanding of four chemical phenomena: Effect of an in-service training course. Journal of Science Teacher Education, 24(4), 763-787. https://doi.org/10.1007/s10972-012-9295-y

Patton, M. Q. (2002). Qualitative evaluation and research methods (3rd ed.). Sage.

Phiri, A. D. K. (2008). Exploring the Integration of Indigenous Science in the Primary School Science Curriculum in Malawi (Doctoral dissertation). Virginia Polytechnic Institute and State University, Blacksburg, Virginia.

Piquette, J. S., \& Heikkinen, H. W. (2005). Strategies reported used by instructors to address student alternate conceptions in chemical equilibrium. Journal of Research in Science Teaching, 42(10), 1112-1134. https://doi.org/10.1002/tea.20091

Polit, D. F., \& Beck, C. T. (2014). Essentials of nursing research: Appraising the evidence for nursing practice (7th ed). Wolters Kluwer/Lippincott Williams \& Wilkins. 
Roth, K. J. (2014). Primary science teaching. In N. G. Lederman \& S. K. Abell (Eds.), Handbook of Research in Science Education (Vol. 2, pp. 361-394). Routledge.

Scerri, E. R., \& McIntyre, L. (2008). The case for the philosophy of chemistry. In E.R. Scerri (Ed.) Collected Papers on Philosophy of Chemistry (pp. 213-232). Imperial College Press.

Schulte, P. L. (2001). Preservice elementary teachers' alternative conceptions in science and attitudes toward teaching science [Unpublished Doctoral Dissertation]. University of New Orleans, New Orleans.

Sunyono, Yuanita, L., \& Ibrahim, M. (2015). Mental models of students on stoichiometry concept in learning by method based on multiple representation. The Online Journal of New Horizon in Education, 5(2), 30-45.

Şenocak, E. (2009). Prospective primary school teachers' perceptions on boiling and freezing. Australian Journal of Teacher Education, 34(4), 27-38. http:// dx.doi.org/10.14221/ajte.2009v34n4.3

Tania, L., \& Fadiawati, N. (2015). Development of interactive e-book based on chemical representation refer to curriculum 2013. Jurnal Pendidikan IPA Indonesia, 4(2), 164- 169. https://doi.org/10.15294/jpii.v4i2.4186

The Council of Higher Education [CoHE]. (May, 2018). Sinıf öğretmenliği lisans programı, yeni öğretmen yetiştirme lisans programlan [Primary school education undergraduate program, new teacher training undergraduate https://www.yok.gov.tr/Documents/Kurumsal/egitim_ogretim_dairesi/Yeni-Ogretmen-YetistirmeLisans-Programlari/Sinif_Ogretmenligi_Lisans_Programi09042019.pdf

Treagust, D. F., Chittleborough, G., \& Mamiala, T. L. (2003). The role of sub-microscopic and symbolic representations in chemical explanations. International Journal of Science Education, 25(11), 1353-1368. https://doi.org/10.1080/0950069032000070306

Tytler, R. (2000). A comparison of Year 1 and Year 6 students' conceptions of evaporation and condensation: Dimensions of conceptual progression. International Journal of Science Education, 22(5), 447-467. https://doi.org/10.1080/095006900289723

Tytler, R., Prain, V., \& Peterson, S. (2007). Representational issues in students' learning about evaporation, Research in Science Education, 37, 313-331. https:// doi.org/10.1007/s11165-006-9028-3

Uluçınar, Ş., Doğan, A., \& Kaya, O. N. (2008). Views of elementary teachers on science teaching and laboratory. Kastamonu Education Journal, 16(2), 485-494.

Uyanık, G. (2015). Determination of the elementary teacher candidates' achievement level of based chemistry concepts. Cumhuriyet International Journal of Education, 4(4), 18-28. https:// doi.org/10.30703/cije.321377

Valanides, N. (2000). Primary student teachers' understanding of the particulate nature of matter and its transformations during dissolving. Chemistry Education: Research and Practice in Europe, 1(2), 249-262. https:// doi.org/10.1039/ A9RP90026H

Wach, E., \& Ward, R. (2013, August). Learning about qualitative document analysis. https://opendocs.ids.ac.uk/opendocs/bitstream/handle/20.500.12413/2989/PP\%20InBrief\%2013\%20Q DA \%20FINAL2.pdf?sequence $=4$

Wishart, J. (2017). Exploring how creating stop-motion animations supports student teachers in learning to teach science. Journal of Research on Technology in Education, 49(1-2), 88-101. https://doi.org/10.1080/15391523.2017.1291316

Yıldırım, A., \& Şimşek, H. (2013). Sosyal bilimlerde nitel araştırma yöntemleri [Qualitative research methods in the social sciences]. Seçkin. 


\section{Appendix. Distillation Experiment Worksheet (DEW)}

1. How can you remove the nail polish on the eyeglass? Please explain.

2. What kind of a mixture of acetone-water can be separated by the distillation technique?

3.

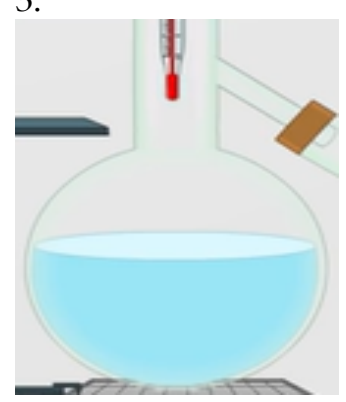

How do the particles of acetone-water mixture move before heating in the distillation flask? Explain and draw the appearance of the particles in the distillation flask.

4.

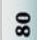

What would you expect to happen when the thermometer shows $56^{\circ} \mathrm{C}$ ?

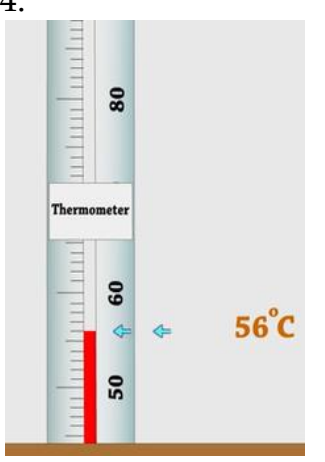

5. What is the first substance to be separated from the mixture?

Please explain your reason

6.

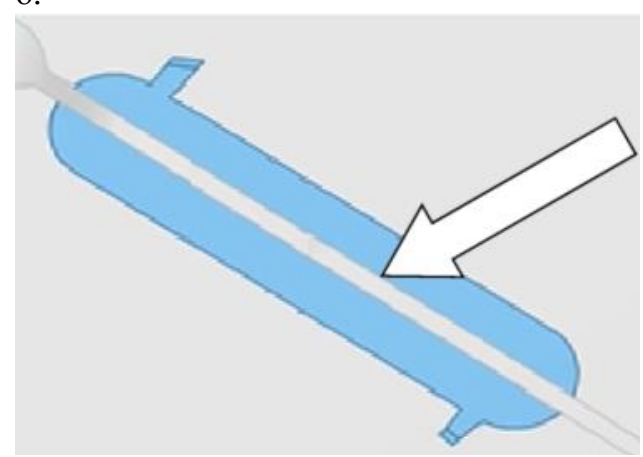

How does the flow of the gas molecules in the glass tube of the Liebig condenser? Show it by drawing on the given figure. 
7.

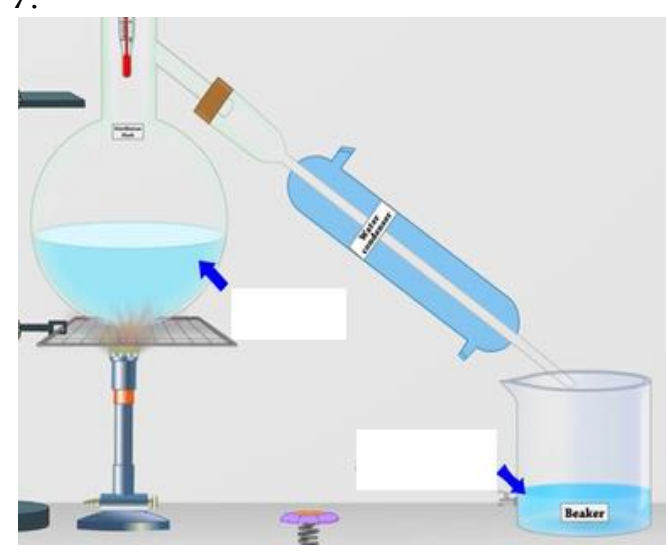

Which substances are found in glass materials indicated by arrows at the end of the distillation experiment? Write it in the white boxes. Please explain your reasons.

8. At the end of the experiment, write the chemical formulas of the substances in the flask and beaker.

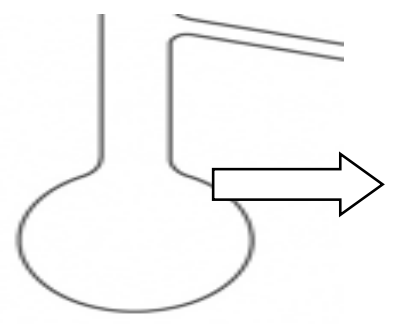

The chemical formula of the substance:

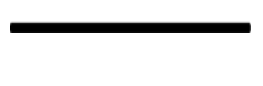

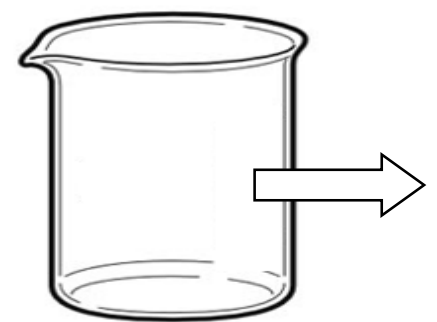

The chemical formula of the substance:

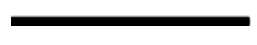

9. What would you expect if methylated spirits consisting of methyl alcohol and water were used as a distillation mixture in this experiment? 